\title{
KOMENTARZE DO USTAW ŁOWIECKICH (CZESKIEJ, SŁOWACKIEJ I POLSKIEJ)
}

\section{COMMENTARIES TO CZECH, SLOVAK AND POLISH HUNTING ACTS}

http://dx.doi.org/10.12775/PPOS.2016.019

\section{STRESZCZENIE}

Przedmiotem opracowania jest syntetyczne spojrzenie na komentarze do trzech obowiązujących ustaw łowieckich: czeskiej z dnia 27 listopada 2001 r., słowackiej z dnia 16 czerwca 2009 r. i polskiej z dnia 13 października 1995 r. Autorzy tego opracowania zajmują się ośmioma komentarzami (dwoma czeskimi, jednym słowackim i pię-

" Dr hab., prof. INP PAN, Zakład Prawa Ochrony Środowiska, Instytut Nauk Prawnych Polskiej Akademii Nauk.

*** Prof. zw. dr hab., Zakład Prawa Ochrony Środowiska, Instytut Nauk Prawnych Polskiej Akademii Nauk. 
cioma polskimi), szukając odpowiedzi na trzy podstawowe pytania: jaką koncepcję dzieła przyjmują komentatorzy, jak sytuują prawo łowieckie w szerszym kontekście prawa ochrony środowiska bądź prawa ochrony przyrody oraz co decyduje o atrakcyjności komentarza jako sposobu objaśnienia pojęć i instytucji prawa łowieckiego.

\title{
Słowa kluczowe
}

Łowiectwo; przyroda; środowisko; prawna ochrona przyrody; prawo ochrony środowiska.

\begin{abstract}
The subject of this paper is a synthetic view of the commentaries on three hunting acts in force: Czech of 27 November 2001, Slovak of 16 June 2009 and Polish of 13 October 1995. The authors of this paper are interested in eight commentaries (two Czech, one Slovak and five Polish) and seek an answer to three basic questions: what is the concept of work presented by commentators, in which way they put hunting law in a larger context of environmental law or nature protection law and what determines the attractiveness of a commentary as a tool to explain terms and institutions of hunting law.
\end{abstract}

\section{Keywords}

Hunting; nature; environment; nature protection; environmental law.

\section{WPROWADZENIE}

Zastanawiające jest, że akurat prawo łowieckie jest wdzięcznym przedmiotem opracowań o charakterze komentatorskim trzech państw bliskich sobie pod względem geograficznym, historycznym, kulturowym, prawnym i językowym. Widać to wyraźnie zwłaszcza w Słowacji i w Polsce. Otóż w literaturze 
słowackiej w dziedzinie prawa środowiska komentarz do ustawy łowieckiej jest jedyny, żadna inna ustawa nie doczekała się opracowania komentatorskiego. W Polsce tylko ustawa Prawo łowieckie była komentowana przez pięć różnych zespołów autorskich, podczas gdy na przykład Prawo ochrony środowiska było komentowane cztery razy, podobnie Prawo wodne. Nieco inaczej jest w Czechach, gdzie ustawa o ochronie przyrody była komentowana przez trzy różne zespoły autorskie, ustawa wodna przez dwa i ustawa łowiecka także przez dwa. W każdym razie właśnie ustawy łowieckie są wyraźnym przykładem aktywności komentatorskiej w tych trzech państwach.

\subsection{CZESKIE PRAWO ŁOWIECKIE}

Czeska ustawa łowiecka z dnia 27 listopada 2001 r. ${ }^{1}$, która weszła w życie 1 lipca 2002 r., kilkunastokrotnie nowelizowana, złożona (po dodaniu § 60a) z 72 paragrafów ${ }^{2}$ została podzielona na następujące jednostki systematyczne:

Część pierwsza. Postanowienia ogólne (§ 1 i 2)

Część druga. Hodowla i uszlachetnianie zwierzyny (§ 3-7)

Część trzecia. Ochrona łowiectwa i ulepszanie warunków życia zwierzyny

Rozdział I. Ochrona łowiectwa (§ 8-11)

Rozdział II. Straż łowiecka (§ 12-16)

Część czwarta. Tworzenie i użytkowanie obwodów łowieckich

Rozdział I. Wnioskowanie o utworzenie obwodów łowieckich (§ 17 i 18)

Rozdział II. Spółka łowiecka (§ 19-28)

1 Zákon č. 449/2001 Sb., o myslivosti. Czeskie akty prawne powołuje się w ten sposób, że po literce „č” (čislo - tj. numer) następuje pozycja, pod którą w oficjalnym zbiorze aktów prawnych - Sbirka zákonů - akt został opublikowany, łamana przez rok publikacji i zakończona literami $S b$., tj. skrótem owego zbioru.

2 Przypominamy, że według koncepcji czeskiej podstawową jednostką systematyczną podziału tekstu prawnego ustaw zwykłych jest nie artykuł (jak w Polsce), lecz paragraf (podział na artykuły występuje w konstytucji i ustawach konstytucyjnych). Taki paragraf może być dzielony na ustępy, niekiedy z dalszym wyodrębnieniem liter, zwłaszcza przy wyliczeniach. 
Rozdział III. Uznanie obwodu łowieckiego i jego zmiany (§ 29-31)

Rozdział IV. Wykorzystanie obwodów łowieckich (§ 32-34)

Część piąta. Gospodarka łowiecka i polowanie

Rozdział I. Gospodarz łowiecki (§ 35)

Rozdział II. Plan gospodarki łowieckiej (§ 36-38)

Rozdział III. Pozwolenie na polowanie w szczególnych przypadkach (§ 39-41)

Rozdział IV. Czasy polowań i warunki polowania (§ 42-44)

Rozdział V. Zakazane sposoby polowania (§ 45)

Rozdział VI. Pozwolenie na polowanie, karta łowiecka i ubezpieczenie obowiązkowe (§ 46-48)

Rozdział VII. Kontrola i spożytkowanie zwierzyny (§ 49-51)

Część szósta. Szkody wyrządzone użytkowaniem obwodu łowieckiego, przez zwierzynę i zwierzynie (§ 52-56)

Część siódma. Państwowa administracja łowiecka

Rozdział I. Organy państwowej administracji łowieckiej i ich kompetencje (§ 57-60a)

Rozdział II. Nadzór w łowiectwie (§ 61)

Rozdział III. Wspieranie gospodarki łowieckiej i stowarzyszeń łowieckich (§ 62)

Część ósma. Sankcje (§ 63 i 64)

Część dziewiąta. Przepisy przechodnie i końcowe (§ 65-70)

Część dziesiąta. Wejście w życie (§ 71).

\subsection{KOMENTARZE CZESKIE}

Czeska ustawa łowiecka była dwukrotnie komentowana. Pierwszy komentarz, którego autorami byli Vladimír Čechura, Rudolf Novák i Jiří Vaněk, został wydany przez Czeskomorawską Jedność Łowiecką w 2002 r. $^{3}$ We wstępie autorzy zastrzegają, że ich komentarz nie jest podręcznikiem dla zdających egzaminy łowieckie, ale przede wszystkim służy jako pomoc dla

3 V. Čechura, R. Novák, J. Vaněk, Komentář k zákonu o myslivosti, Praha 2002. 
tych, którzy będą realizować ustawę w praktyce; zwłaszcza dla właścicieli gruntów łowieckich, spółek łowieckich, pracowników administracji państwowej i myśliwych. Odżegnują się od pogłębionej interpretacji ustawy, nie chcą, jak piszą, ingerować w kompetencje ustawodawcy i sądów. Mimo to są przekonani, że pewien pogląd na sposób realizacji lub zrozumienie niektórych przepisów ustawy może być wielce pomocny i jest oczekiwany nie tylko przez myśliwych.

Warto zwrócić uwagę, że ten komentarz ukazał się niemal natychmiast po wejściu w życie czeskiej ustawy łowieckiej z 2001 r. Nic tedy dziwnego w tym, że autorzy główną uwagę skierowali na to, jakie zmiany nowa ustawa wnosi w porównaniu z poprzednią, jeszcze czechosłowacką, ustawą łowiecką ${ }^{4}$. Autorzy przytaczają obszerne fragmenty oficjalnych motywów ustawodawczych (di̊vodové zprávy) do projektów nowej ustawy łowieckiej, po czym bardzo starannie analizują przepisy ustawy według nie tylko paragrafów, lecz także ustępów i liter, wskazując na sankcje grożące za ich naruszenie. Jak wielką wagę autorzy przywiązują do sankcji, dobitnie wskazuje zamieszczony na s. 230-232 schemat obowiązków, które są sankcjonowane jako wykroczenia (prestupky) z § 63 lub inne naruszenia z § 64. Autorzy wyliczają 64 naruszenia obowiązków sankcjonowanych przez § 63 i 64.

Autorzy nie unikają pewnych rozważań o charakterze teoretycznym. Na uwagę zasługuje ich podejście do definicji łowiectwa (myslivost) zamieszczonej w $\S 2$ lit. a), która głosi, że jest to całokształt działań prowadzonych w przyrodzie w odniesieniu do dziko żyjącej zwierzyny jako części składowej ekosystemu oraz działalność wspólna zmierzająca do utrzymania i rozwijania tradycji i zwyczajów myśliwskich jako części składowej czeskiego narodowego dziedzictwa kulturowego. $\mathrm{Na}$ tym tle autorzy komentarza wyrażają pogląd (s. 9), że definicja zawiera w sobie raczej działania ochronne niż gospodarcze. Łowiectwa nie można traktować jako prowadzenia działalności gospodarczej (podnikani), nie można z tej definicji wyprowadzać wniosku, że chodzi o zaspokajanie zainteresowań (za-

${ }^{4}$ Zákon č. 23/1962 Sb., o myslivosti. 
jimavá činnost), upodobań (záliba), sport czy tylko polowanie (lovectvi). Wprawdzie nie ma tu jeszcze wyraźnego wskazania, że łowiectwo jest elementem ochrony środowiska, ale wywód autorów ku temu zmierza.

Drugi czeski komentarz ukazał się po trzynastu latach ${ }^{5}$ w wydawnictwie Wolters Kluwer. Jest on dziełem zbiorowym sześciu autorów. W skład zespołu autorskiego wchodzą:

1) Bohuslav Petr - kierujący zespołem autorskim, doktor nauk prawnych, sędzia i pracownik naukowy;

2) Vladimír Čechura - leśnik i prawnik, współautor poprzedniego komentarza;

3) Jaroslav Kostečka - inżynier leśnik, pedagog i badacz, aktywny myśliwy i kynolog, publicysta myśliwski;

4) Hubert Maxa - prawnik, zajmuje się prawem egzekucyjnym i prawnymi aspektami łowiectwa;

5) Jindřich Petr - absolwent studiów rolniczych, zajmuje się prawem $\mathrm{w}$ dziedzinach rolnictwa, ochrony przyrody, leśnictwa, łowiectwa i rybactwa;

6) Jaroslav Šprongl - z wykształcenia matematyk, ale faktycznie dramaturg, wydawca, scenarzysta, tekściarz; autor licznych opracowań z zakresu łowiectwa, w tym cyklu telewizyjnego Tysiąc lat czeskiego łowiectwa.

W przedmowie (s. XVII-XXI) kierujący zespołem autorskim przedstawił zarys dziejów łowiectwa na ziemiach czeskich i krótko scharakteryzował obowiązującą czeską ustawę łowiecką. Zwrócił uwagę, że ze względu na wejście w życie z dniem 1 stycznia 2014 r. nowego czeskiego kodeksu cywilnego ${ }^{6}$, pojawiła się już konieczność rekodyfikacji ustawy łowieckiej z powodu potrzeby ujednolicenia terminologii łowieckiej i kodeksu cywilnego.

Sam tekst komentarza liczy 272 strony, po których następuje starannie opracowany indeks rzeczowy (s. 273-277).

Układ komentarza ma charakter klasyczny. Po tekście paragrafu następują szczegółowe wyjaśnienia odnoszące się najpierw do całości, potem do poszczególnych ustępów i liter. 
Po nich następuje Judikatura obejmująca najważniejsze fragmenty orzeczeń sądowych (Sądu Konstytucyjnego, Sądu Najwyższego, Najwyższego Sądu Administracyjnego, niekiedy także sądów niższych instancji). Po orzecznictwie, pod nagłówkiem Souvisijecí ustanovení, autorzy wskazują na przepisy samej ustawy łowieckiej wiążące się z komentowanym paragrafem, po czym pod nagłówkiem Souvisijecí predpisy wskazują na inne niż ustawa łowiecka akty prawne (np. kodeks cywilny, kodeks karny, ustawa o wykroczeniach, ustawa weterynaryjna, ustawa komunikacyjna itp.), które odnoszą się do komentowanego paragrafu. Komentarz do większości paragrafów kończy Literatura, przy czym w zdecydowanej większości przywoływane są artykuły publikowane na łamach czasopism łowieckich takich, jak Myslivost bądź Svět myslivosti. Bardzo rzadko pojawiają się artykuły z czasopism prawniczych, a jeśli chodzi o pozycje książkowe $\mathrm{z}$ dziedziny prawa łowieckiego, to w komentarzu do $\S 1$ ustawy pojawia się jedna ${ }^{7} \mathrm{i}$ to jeszcze wydana przed obowiązującą ustawą łowiecką. Innych książkowych pozycji poświęconych prawu łowieckiemu nie ma, a przyczyna jest bardzo prosta - takich pozycji w ogóle w Czechach nie ma. Zastanawiające natomiast jest, dlaczego autorzy komentarza do ustawy łowieckiej nie sięgnęli do odpowiedniej części „brneńskiego” podręcznika prawa środowiska, mimo że autor odnośnej części ${ }^{8}$ podbudował ją teoretycznie, precyzując m.in. zasady prawa łowieckiego.

W kwestii charakteru prawnego łowiectwa autorzy powtórzyli pogląd komentatorów z 2002 r., używając dokładnie takich samych sformułowań: definicja łowiectwa wskazuje raczej na działalność ochronną niż gospodarczą, a łowiectwo nie jest zaspokajaniem zainteresowań, upodobaniem, sportem ani tylko polowaniem. Mieli wszakże więcej argumentów. Przytoczyli w komentarzu wyrok czeskiego Sądu Konstytucyjnego z 2003 r. oznaczony sygnaturą Pl. ÚS 34/03, w którym czytamy:

7 V. Čechura a kolektiv, Myslivost a právo, Praha 2000.

8 M. Pekarek, Právní režim myslivosti, w: Kolektiv autorů, Právo životního prostředí. 2. dil, Brno 2006, s. 259-287; w nowym wydaniu: M. Pekarek, Ochrana živočichů v rámci myslivosti, rybářstvi a včelařstvi, w: Ilona Jančařová a kolektiv, Pravo životního prostředí: Zvláštní část, Brno 2015, s. 308-359. 
„W warunkach Republiki Czeskiej łowiectwo i prawo łowiectwa są społecznymi aktywnościami aprobowanymi przez państwo dla ochrony i rozwoju jednego z komponentów środowiska zwierzyny. Ustawa łowiecka nie przedstawia regulacji łowiectwa jako aktywności zmierzającej do realizacji zainteresowań, ale w swej podstawie jako świadomego celu i regulowanego działania dla ochrony i rozwoju przyrody. Realizacja łowiectwa i prawa łowiectwa jest w płaszczyźnie ogólnej legitymowanym ograniczeniem prawa własności, a za ich pośrednictwem państwo wykonuje swój konstytucyjny obowiązek zakotwiczony w art. 7 Konstytucji". Przypomnimy, że art. 7 Konstytucji Republiki Czeskiej stanowi: „Państwo dba o zrównoważone ${ }^{9}$ wykorzystywanie zasobów przyrodniczych i ochronę bogactwa przyrodniczego".

Wprawdzie komentatorzy nie formułują wprost poglądu o przynależności prawa łowieckiego do prawa ochrony przyrody (právo ochrany př́rody), będącego częścią składową prawa środowiska (právo životního prostředi), ale przytoczenie, i to w kilku miejscach komentarza, tego orzeczenia pozwala przypuszczać, że utożsamiają się ze stanowiskiem Sądu Konstytucyjnego.

\subsection{SŁOWACKIE PRAWO ŁOWIECKIE}

Słowacka ustawa łowiecka z 16 czerwca 2009 r. ${ }^{10}$, która weszła w życie 1 września 2009 r., kilkakrotnie nowelizowana,

9 W oryginale - šetrné, co słowniki oddają jako „oszczędne”, ale także „mające wzgląd na innych, delikatne, taktowne”, stąd nasz pomysł przekładu przez „zrównoważone”, co chyba oddaje intencję.

10 Zákon č. 274/2009 Z.z. o pol'ovníctve. Słowackie akty prawne powołuje się w ten sposób, że po literce „č” (čislo - tj. numer) następuje pozycja, pod którą w oficjalnym zbiorze aktów prawnych - Zbierka zákonov - akt został opublikowany, łamana przez rok publikacji i zakończona literami Z.z., tj. skrótem owego zbioru. 
składa się z sześciu oznaczonych cyframi artykułów (članky) ${ }^{11}$ i trzech załączników. Artykuł I złożony (po dodaniu 5 paragrafów wprowadzonych nowelizacjami, oznaczonych dodatkowo literami) z 89 paragrafów został podzielony na jednostki systematyczne nienazwane rozdziałami i nienumerowane, obejmujące $\mathrm{z}$ reguły kilka paragrafów:

Przepisy podstawowe (przedmiot regulacji w $\S 1$ i definicje $\mathrm{w} \S 2$ )

Obwód łowiecki (§ 3-10)

Wykorzystywanie obwodu łowieckiego (§ 11-17)

Gospodarowanie łowieckie (§ 18 i 19)

Hodowla zwierzyny (§ 20-23)

Ochrona i polepszanie warunków życia zwierzyny (§ 24-26)

Straż łowiecka (§ 27-29)

Planowanie łowieckie, statystyka i system informatyczny (§ 30 i 31)

Organizacja łowiecka, Słowacka Izba Łowiecka (§ 32-49)

Egzaminy łowieckie, karta łowiecka i pozwolenie na polowanie (§ 50-53)

Polowanie na zwierzynę (§ 54-65)

Spożytkowanie upolowanej zwierzyny (§ 66-68)

Szkody wyrządzone polowaniem, przez zwierzynę i zwierzynie (§ 69 i 70)

Państwowa administracja łowiecka (§ 71-75)

Wykroczenia, przewinienia dyscyplinarne i inne delikty administracyjne (§ 76-78)

Przepisy wspólne, przechodnie i końcowe (§ 79-84).

Artykuły II-V zmieniają cztery ustawy: o stowarzyszeniach, o opłatach administracyjnych, o dzierżawie gruntów rolnych i leśnych oraz weterynaryjną.

Artykuł VI wskazuje na termin wejścia w życie ustawy.

11 Słowacki članok ma tu nieco inne, historycznie uzasadnione znaczenie. Tak jak w Czechach, tak też w Słowacji artykuł jest podstawową jednostką systematyczną podziału normowanej materii w konstytucji i ustawach konstytucyjnych, w ustawach zwykłych taką jednostką jest paragraf. Ale tu clanok I to cała ustawa łowiecka, podzielona na paragrafy. 
Słowacka ustawa łowiecka została opatrzona trzema załącznikami:

1. Wykaz populacji wolno żyjących gatunków zwierząt

2. Stawki służące do obliczenia czynszu

3. Wykaz przejmowanych aktów unijnych, jakimi są:

a) dyrektywa Rady 79/409/EWG w sprawie ochrony dzikiego ptactwa ${ }^{12}$,

b) dyrektywa Rady 92/43/EWG w sprawie ochrony siedlisk przyrodniczych oraz dzikiej fauny i flory ${ }^{13}$,

c) dyrektywa Parlamentu Europejskiego i Rady 2009/147/WE w sprawie ochrony dzikiego ptactwa ${ }^{14}$.

\subsection{KOMENTARZ SŁOWACKI}

Słowacki komentarz do wybranych przepisów ustawy łowieckiej ${ }^{15}$, który ukazał się w wydawnictwie Wolters Kluwer, jest dziełem dwóch autorów; zarówno Martin L'upták, jak i Matúš Sarvaš są prawnikami, aktualnie pracującymi w organach prokuratury. Komentarz jest zasadniczo odmienny od obu komentarzy czeskich przede wszystkim dlatego, że to nie jest komentarz do całości ustawy łowieckiej, lecz jedynie do jej wybranych przepisów. Sami autorzy określają go jako swego rodzaju przewodnik (sprievodný výklad) po nowej regulacji łowieckiej.

Układ komentarza jest następujący: po przytoczeniu na s. 13-15 krótkich fragmentów oficjalnych motywów ustawodawczych (dôvodové správy) do samej ustawy łowieckiej z 2009 r. i jej nowelizacji z 2013 r., na s. 16-207 następuje komentarz do przepisów odnoszących się do:

- obwodów łowieckich (§ 3-5),

- zmiany granic obwodu łowieckiego (§ 9 i 10),

12 Dz. Urz. UE L 103 z 25.4.1979, s. 1-18.

13 Dz. Urz. UE L 206 z 22.7.1992, s. 7-50.

14 Dz. Urz. UE L 20 z 26.1.2010, s. 7-25.

15 M. L'upták, M. Sarvaš, Zákon o pol'ovníctve. Komentár k vybraným ustanoveniam, Bratislava 2015. 
- wykorzystywania obwodu łowieckiego (§ 11-17),

- ochrony łowiectwa i straży łowieckiej (§ 24-29),

- organizacji łowieckich i Słowackiej Izby łowieckiej (§ 32-49),

- gospodarza łowieckiego (§ 19),

- ubezpieczenia przy wykonywaniu prawa polowania (§ 52).

Po części komentarzowej następują załączniki: najpierw na s. 208-216 Instrukcja Ministerstwa Gospodarki Rolnej i Leśnej Republiki Słowackiej w sprawie wykazywania uprawnień do wykorzystywania dróg leśnych i korzystania z gruntów leśnych, następnie na s. 217-383 orzeczenia sądowe. Dzieło kończy wskazanie na wykorzystaną literaturę (s. 384), wśród której znajdują się dwa słowackie komentarze do kodeksu cywilnego, słowacki komentarz do ustawy o postępowaniu administracyjnym oraz czeski przegląd orzecznictwa w sprawach karania administracyjnego ${ }^{16}$, a także wskazanie na wykorzystaną judykaturę (s. 385-386): 15 orzeczeń Sądu Najwyższego Republiki Słowackiej, 4 orzeczenia Sądu Konstytucyjnego Republiki Słowackiej, 3 orzeczenia innych sądów (orzeczenia sądów okręgowych w Bańskiej Bystrzycy i Nitrze oraz orzeczenie Najwyższego Sądu Administracyjnego Republiki Czeskiej).

Spośród 89 paragrafów słowackiej ustawy łowieckiej autorzy skomentowali 38, czyli poniżej połowy (dokładnie 42,6\%). Z jednej strony są to przepisy kluczowe dla zrozumienia regulacji łowieckich, skoro odnoszą się do obwodów łowieckich, ochrony łowiectwa i organizacji łowiectwa. Zwraca uwagę przede wszystkim obszerny komentarz do § 24 (s. 98-125) poprzedzony przez autorów adnotacją, że ochrona dziko żyjącej zwierzyny jest jedną z podstawowych dziedzin, której służy regulacja prawa zawarta w ustawie łowieckiej. Dalej autorzy wskazują, że obowiązek ochrony środowiska został nałożony na każdą osobę znajdującą się na terytorium Republiki Słowackiej przez art. 44 Konstytucji, a konkretniejsza regulacja prawa znajduje się w pię-

16 Trudno dociec, dlaczego autorzy nie przywołali słowackiego komentarza do czechosłowackiej ustawy łowieckiej z 1962 r. J. Matečny a kolektiv, Právne predpisy o pol'ovnictve, Bratislava 1977. 
ciu ustawach: o środowisku, o ochronie przyrody i krajobrazu, leśnej, wodnej i o ochronie powietrza, po czym dokładnie omawiają regulacje ochronne ustawy o ochronie przyrody i krajobrazu, ustawy leśnej i ustawy wodnej, sytuując je w kontekście ochrony łowiectwa w rozumieniu § 24 ustawy łowieckiej. Udane jest także wyczerpujące skomentowanie charakterystycznej dla ustawy słowackiej instytucji gospodarza łowieckiego (§ 19), obligatoryjnie powoływanego przez urząd powiatowy na wniosek użytkownika obwodu łowieckiego (s. 194-202). Z drugiej jednak strony pozostawienie poza uwagami komentatorskimi przepisów § 1 i 2 ustawy łowieckiej nieco utrudniło autorom wyraźne usytuowanie łowiectwa w ramach porządku prawnego i tylko z uwag do § 24 można wnioskować, że zaliczają prawo łowieckie do prawa środowiska. Komentatorzy nie mogli jeszcze uwzględnić niemal jednocześnie wydanego słowackiego podręcznika tej dziedziny prawa ${ }^{17}$. Autor rozdziału części szczególnej poświęconego łowiectwu śmiało stawia tezę, że łowiectwo jest niedającą się oddzielić częścią składową ochrony środowiska (pol'ovnictvo je neoddelitel'nou súčast'ou ochrany životného prostredia), przy czym jedna z tych części bez drugiej nie może istnieć. Chodzi o niedającą się oddzielić część składową stosowanej ochrony przyrody (ide o neoddelitel'nú súčast' aplikovanej ochrany prírody) ${ }^{18}$. Jest to, być może, najwyraźniejsza deklaracja, że łowiectwo jest elementem ochrony przyrody, a tym samym ochrony środowiska.

Zwraca uwagę potraktowanie przez komentatorów orzecznictwa sądowego. Zajmuje ono 167 stron dzieła, przy czym to nie są jedynie tezy, ale obszerne fragmenty orzeczeń obrazujące drogę do zajęcia ostatecznego stanowiska. Nie wszystkie z nich dotyczą bezpośrednio łowiectwa, niektóre nie mają z łowiec-

17 Branislav Cepek a kolektiv, Environmentálne právo. V̌̌eobecná a osobitná čast’, Plzeň 2015. Zwraca uwagę ów anglicyzm - environmentálne, który po raz pierwszy pojawia się w tytule dzieła. Na ogół autorzy słowaccy posługują się pojęciem právo životného prostredia (zob. np. Soňa Košičiarová a kolektiv, Právo životného prostredia, Bratislava 2009), ale dość często traktują je zamiennie z pojęciem environmentálne právo.

18 A. Martvoň, Starostlivost' o zver a pol'ovnictvo, w: B. Cepek a kolektiv, Environmentálne právo, s. 319. 
twem nic wspólnego, np. orzeczenia dotyczące instytucji obrony koniecznej, doręczenia zastępczego czy innych kwestii procesowych. Jeżeli dobrze odczytujemy intencję komentatorów, chodziło im o wskazanie sposobu rozstrzygania niektórych kwestii prawnych mogących mieć znaczenie także w łowiectwie. Najważniejszym przytoczonym przez komentatorów jest orzeczenie Sądu Konstytucyjnego z 8 marca 2012 r., oddalające skargę właścicieli gruntów w obwodzie łowieckim, domagających się wyłączenia ich gruntów z obwodu łowieckiego (s. 344-359), przedstawiające szczegółową analizę uprawnień płynących z własności nieruchomości $\mathrm{w}$ zderzeniu $\mathrm{z}$ interesem publicznym, jakim jest wykonywanie łowiectwa.

Podsumowując krótko uwagi o komentarzach czeskich i słowackich, można odnieść wrażenie, że są to komentarze wielofunkcyjne, zastępujące monografie naukowe poświęcone prawu łowieckiemu, których ani w Czechach, ani w Słowacji nie ma.

\section{POLSKIE PRAWO ŁOWIECKIE}

\subsection{USTAWA PRAWO ŁOWIECKIE}

Trzon prawnej regulacji łowiectwa w Polsce stanowi ustawa z dnia 13 października 1995 r. Prawo łowieckie ${ }^{19}$. Struktura ustawy opiera się na dwunastu rozdziałach, zatytułowanych kolejno:

1. Przepisy ogólne (art. 1-5)

2. Organy administracji w zakresie łowiectwa (art. 6-7)

3. Zasady gospodarki łowieckiej (art. 8-16)

4. Działalność gospodarcza w zakresie łowiectwa (art. 18$-22 b)$

5. Obwody łowieckie (art. 23-31)

6. Polski Związek Łowiecki (art. 32-35a)

19 Tekst jedn. Dz. U. z 2015 r., poz. 2168 ze zm. 
6a. Odpowiedzialność dyscyplinarna (art. 35b-35t)

7. Straż łowiecka (art. 36-41)

8. Wykonywanie polowania (art. 42-45)

9. Szkody łowieckie (art. 46-50)

10. Przepisy karne (art. 51-54)

11. Zmiany w przepisach obowiązujących, przepisy przejściowe i końcowe (art. 58-64).

\subsection{KOMENTARZE POLSKIE}

Obowiązująca polska ustawa łowiecka była dotychczas komentowana pięciokrotnie (kolejne wydania pracy danego autora liczymy jako jedno dzieło).

Biorąc pod uwagę kryterium chronologiczne, fundament pod dorobek komentatorskiej literatury prawniczej, odnoszącej się do polskiego prawa łowieckiego, postawił w 1996 r. Wojciech Radecki, profesor nauk prawnych zajmujący się przede wszystkim szeroko pojmowanych prawem ochrony środowiska. Wydał on we wrocławskim Wydawnictwie Towarzystwa Naukowego Prawa Ochrony Środowiska komentarz do Prawa łowieckiego ${ }^{20}$. Następnie, reagując na zmiany stanu prawnego, W. Radecki opublikował dotychczas pięć (w latach: 2005, 2007, 2010, 2012, 2014) wydań komentarza do ustawy Prawo łowiec$\mathrm{kie}^{21}$. To ostatnie wydanie stanowić będzie przedmiot naszych rozważań.

Konstrukcja dzieła oparta jest na dwóch częściach: 1) obszernym wprowadzeniu do problematyki prawa łowieckiego, obejmującym historię tej dziedziny regulacji prawnej oraz umiejscawiającym prawo łowieckie w systemie prawa polskiego; 2) komentarzu do przepisów ustawy Prawo łowieckie.

Wojciech Radecki traktuje prawo łowieckie (czyli kompleks przepisów prawnych, na który składa się ustawa Prawo łowieckie, a także przepisy aktów wykonawczych do niej i przepisów innych aktów mających znaczenie dla łowiectwa) jako

20 W. Radecki, Prawo towieckie z komentarzem, Wrocław 1996.

21 W. Radecki, Prawo towieckie. Komentarz, Warszawa 2014. 
fragment szeroko rozumianego prawa ochrony środowiska. Prawo łowieckie wchodzi w skład części szczególnej prawa ochrony środowiska, a konkretnie stanowi konwencjonalnie wyodrębnioną dziedzinę prawa ochrony przyrody. Autor zdecydowanie podkreśla, że łowiectwo obejmuje dwa podstawowe elementy: ochronę zwierzyny i gospodarowanie nią, przy czym nie jest przypadkiem, że ochrona została wysunięta na plan pierwszy ${ }^{22}$. Można utrzymywać, że w łowiectwie (jak też w leśnictwie i rybactwie) liczy się nie tylko ochrona, ale także gospodarowanie i zarządzanie, ale nie do pomyślenia jest racjonalne gospodarowanie i zarządzanie bez ochrony ${ }^{23}$.

Taki sposób prawnego umiejscowienia łowiectwa implikuje kształt komentarza W. Radeckiego, którego znaki szczególne stanowią:

1. Prymat zainteresowania przepisami o charakterze ochronnym, co jest odzwierciedleniem przyjętej przez Autora koncepcji łowiectwa.

2. Ukazanie łowiectwa i jego instytucji prawnych nie „obok" innych części (instytucji) systemu prawnego szczególnie tego związanego z ochroną środowiska, ale „w związku”, „na tle”, „we wzajemnym oddziaływaniu”.

3. Wnikliwa analiza przepisów karnych, które w łowiectwie odgrywają ogromną rolę, a ich stosowanie jest trudne, co pokazuje praktyka.

4. Szerokie odnoszenie się do dotychczasowych poglądów zgłaszanych w literaturze i interpretacji przepisów przyjmowanych $\mathrm{w}$ praktyce stosowania prawa.

5. Poważne i wnikliwe traktowanie wykładni historycznej (często zapominanej i niedocenianej), jako jednej z metod objaśniania i odnajdywania sensu tekstu prawnego.

Jako cechę pracy W. Radeckiego należy potraktować także wyróżniającą wytrwałość i ciągłość pracy autora, co jest źródłem swoistej, posługując się terminologią ekonomiczną, przewagi konkurencyjnej, na tle innych przywoływanych dzieł. Mianowicie do omawianej pracy trafnie może być odnoszony termin

22 Op. cit., s. 56.

23 Op. cit., s. 52. 
in statu nascendi, czyli „,w trakcie powstawania”, „w czasie tworzenia", którego sens można modyfikować w zależności od zmieniającego się otoczenia prawnego. Warto tu zwrócić uwagę, że pierwsze „łowieckie” przedsięwzięcie komentatorskie W. Radeckiego miało miejsce $\mathrm{w}$ zupełnie innym stanie prawnym (kiedy nie obowiązywała jeszcze ustawa Prawo ochrony środowiska z 2001 r. ani ustawa o ochronie przyrody z 2004 r.), zaś kolejne skorelowane są z istotnymi zmianami stanu prawnego. Taka ciągłość pozwala śledzić przemiany instytucji prawnych, rozwój myśli naukowej i praktycznej ich dotyczącej, a także ewolucję poglądów Autora na określone zjawiska prawne.

W 1998 r. ukazały się dwie pozycje: praca Marii Jolanty Skockiej i Janusza Szczepańskiego ${ }^{24}$ oraz opracowanie Tadeusza Mullera i Zygmunta Zwolaka ${ }^{25}$. Nieco wcześniejsze jest pierwsze z tych opracowań.

Maria Jolanta Skocka przedstawiła się jako radca prawny pracujący w Ministerstwie Ochrony Środowiska, Zasobów Naturalnych i Leśnictwa (zgodnie z terminologią z końca lat 90.); Janusz Szczepański to socjolog, działacz Polskiego Związku Łowieckiego, również były pracownik Ministerstwa Ochrony Środowiska, Zasobów Naturalnych i Leśnictwa.

Ich opracowanie, liczące ok. 450 stron, podzielone jest na: 1) tekst ustawy Prawo łowieckie, a następnie komentarz do poszczególnych przepisów (ok. 140 stron); 2) przytoczenie przepisów wykonawczych i przepisów związanych z łowiectwem; 3) omówienie prawnofinansowych aspektów działalności kół łowieckich wraz z aspektami rachunkowości i ogólnymi kwestiami podatkowymi. Część stricte komentatorska to ok. 115 stron.

M.J. Skocka i J. Szczepański już we wstępie podkreślają mocno krytyczny stosunek do kształtu ustawy Prawo łowieckie. Ich zarzuty dotyczą tego, że ustawa z 1995 r. w swoich głównych założeniach i koncepcji ich realizacji jest powieleniem

24 M.J. Skocka, J. Szczepański, Prawo łowieckie. Komentarz, Warszawa 1998.

25 T. Muller, Z. Zwolak, Prawo łowieckie z komentarzem oraz przepisami wykonawczymi i zwiąkowymi, Warszawa 1998. 
modelu wprowadzonego w Polsce po 1944 r. Wyraźnym tego przykładem są chociażby takie instytucje prowadzenia gospodarki łowieckiej, jak: obwody łowieckie, koła łowieckie lub też uprawnienia do wykonywania polowania. Mimo demokratyzacji życia społecznego nie dokonano demokratycznych zmian w strukturze podstawowych jednostek zajmujących się gospodarką łowiecką, nie określono jasno uprawnień kół łowieckich i członków tych kół. Jedyną wyraźną zmianą w stosunku do poprzednio obowiązującej ustawy jest położenie nacisku na problem ochrony przyrody, w tym zwierzyny. Oprócz kwestii merytorycznych ustawie można zarzucić niską jakość legislacyjną, widoczną zwłaszcza pod względem precyzji językowej. Autorzy zastanawiają się, czy nowa ustawa w ogóle była potrzebna, skoro nie wprowadziła nowych rozwiązań w łowiectwie, nie poprawiła błędów poprzedniej ustawy, a przeciwnie - dodała następne.

Jako zadanie stojące przed swym opracowaniem M.J. Skocka i J. Szczepański wskazują wypunktowanie niedoskonałości ustawy Prawo łowieckie. W szczególności chcą uwidocznić luki prawne, wewnętrzną niespójność, nieprecyzyjność i powierzchowność norm. Zakładają, że nie będą podawać recepty na rozwiązanie problemów, jakie taki stan stwarza, pozostawiając to orzecznictwu sądowemu (s. XV). Właśnie poprzez ukazanie trudności, ale bez wskazania choćby propozycji rozwiązań, autorzy widzą nietypowość swojego opracowania.

Podkreślają ustawowe potraktowanie łowiectwa jako elementu ochrony środowiska, co ma spełnić ważną rolę w zrównoważonym rozwoju wszystkich elementów składających się na środowisko. Wydaje się to być również wyrazem ograniczenia tradycyjnie rozumianego łowiectwa, przede wszystkim myślistwa (s. 33). Ochrona przyrody - w szczególności ochrona zwierzyny potraktowana jest jako jedna z zasad gospodarki łowieckiej, przede wszystkim przez tworzenie warunków bezpiecznego bytowania zwierzyny (s. 46).

Zarówno Tadeusz Muller, jak i Zygmunt Zwolak byli działaczami Polskiego Związku Łowieckiego i, jednocześnie, myśliwymi. Obaj ukończyli studia prawnicze, Zygmunt Zwolak wykonywał zawód prokuratora. 
T. Muller i Z. Zwolak przyjmują układ, w którym najpierw następuje omówienie historii prawa łowieckiego w Polsce (część I), następnie klasyczny komentarz kolejnych przepisów ustawy Prawo łowieckie (część II), dalej przytoczone są przepisy wykonawcze do ustawy Prawo łowieckie (część IV), a na końcu przywołane i zacytowane zostały wybrane akty prawne regulujące problematykę łowiectwa (część IV).

Autorzy sytuują łowiectwo na tle ochrony środowiska przyrodniczego, pisząc, że „cel prawny łowiectwa to przede wszystkim ochrona zwierząt łownych” (s. 33). Jako kanony, na których opiera się model polskiego łowiectwa (ich zdaniem uznawanego za wzorcowy przez wszystkie międzynarodowe organizacje łowieckie), wymieniają: 1) szczególną pozycję Polskiego Związku Łowieckiego, do którego przynależność jest niezbędnym warunkiem uprawiania łowiectwa; 2) państwową własność zwierzyny; 3) oparcie gospodarki łowieckiej na samodzielnych, aczkolwiek zrzeszonych w PZŁ kołach łowieckich, dzierżawiących poszczególne obwody łowieckie (s. 30-31). Opowiadają się za modelem, w którym gospodarka łowiecka stanowi równorzędną dziedzinę względem gospodarki rolnej, leśnej i rybackiej - każdy z tych działów, ściśle związanych w ramach ochrony środowiska, ma samoistne znaczenie gospodarcze (s. 34). Zwraca uwagę, że łowiectwo jest - dla autorów - sferą ważną nie tylko ze względów przyrodniczych i gospodarczych, ale także poprzez zaspokajanie duchowych potrzeb człowieka. Charakterystyczne w tym względzie są rozważania prowadzone na tle ustawowo wskazanych celów łowiectwa (s. 37-38).

Generalnie uwagi komentatorskie są wnikliwe, przemyślane i przebija przez nie dogłębna znajomość praktyki łowieckiej. Za pewien mankament można potraktować oszczędne odwoływanie się do literatury i orzecznictwa, co jednak można chyba wytłumaczyć położeniem nacisku przede wszystkim na problemy praktyki. Podobnej natury jest postulat mocniejszego zaakcentowania prawnej istoty łowiectwa - w ten sposób, że stanowi ono część prawa ochrony środowiska, w tym przyrody, z tym jednak, że autorów, przynajmniej częściowo, tłumaczy 3/2016 aktualny w chwili pisania dzieła stan prawny, w którym obo- 
wiązywała jeszcze ustawa o ochronie i kształtowaniu środowiska z 1980 r. i ustawa o ochronie przyrody z 1991 r.

Rok 2014 przyniósł pracę zbiorową Bartosza Rakoczego, Romana Steca i Agnieszki Woźniak ${ }^{26}$. W gruncie rzeczy jest to książka przygotowana przede wszystkim przez R. Steca, bowiem B. Rakoczy jest autorem uwag komentatorskim do rozdziału 9 (Szkody łowieckie), zaś A. Woźniak omówiła zaledwie dwa artykuły (40 i 41) poświęcone strażnikom łowieckim.

Bartosz Rakoczy to profesor nauk prawnych specjalizujący się $\mathrm{W}$ prawie ochrony środowiska, a dodatkowo radca prawny. Roman Stec to doktor nauk prawnych zajmujący się prawem ochrony środowiska, a także czynny myśliwy. Agnieszka Woźniak, nauczyciel akademicki, zajmuje się problematyką prawnych aspektów bezpieczeństwa i porządku publicznego.

Cechy charakterystyczne przyjętej przez autorów koncepcji wydają się stanowić: 1) skomentowanie wszystkich przepisów ustawy i rozporządzeń przez pryzmat ponad 30-letnich doświadczeń łowieckich jednego z Autorów, z odwoływaniem się do rzecznictwa i doktryny; 2) równorzędne potraktowanie przepisów o charakterze ochronnym, ustrojowym, regulujących zasady gospodarki łowieckiej, karnych, o polowaniu, szkodach łowieckich, obwodach łowieckich, Polskim Związku Łowieckim, organach administracji właściwych w sprawach łowiectwa; 3) wskazaniu miejsc w prawie łowieckim, gdzie potrzebna jest interwencja ustawodawcy (wstęp, s. 11-14).

Dosyć zagadkowe pozostaje zawarte we wstępie stwierdzenie, że „Autorzy przedstawili prawne zagadnienia gospodarki łowieckiej i łowiectwa w innym aspekcie, niż czyni to W. Radecki", nigdzie dalej nie wyjaśniając na czym ta odmienność wynika. Równie enigmatyczne, a nawet nielogiczne jest dalsze wskazanie (s. 12), że komentarz nie jest konkurencją dla opracowań W. Radeckiego. Skoro - jak twierdzą autorzy - przedstawia problemy $\mathrm{w}$ innym aspekcie i jednocześnie kierowany jest do tego samego czytelnika, to konkurencją być musi, co zresztą na rynku wydawniczym jest oczywiste. 2014.

B. Rakoczy, R. Stec, A. Woźniak, Prawo łowieckie. Komentarz, Warszawa 
Prawo łowieckie jest sytuowane w obrębie prawa ochrony środowiska, co autorzy podkreślają pisząc o zgodności zasad gospodarki łowieckiej (najważniejszej części ustawy Prawo łowieckie) z zasadami prawa ochrony środowiska (s. 29). „Łowiectwo jest szczególną dziedziną życia społecznego łączącą $\mathrm{w}$ sobie harmonijnie ochronę przyrody i tradycje myśliwskie. Poprzez zabiegi hodowlane powinno przyczyniać się z jednej strony do stwarzania optymalnych warunków przyrodniczych zwierzętom łownym, a z drugiej pozwalać na skuteczną ochronę gatunków rzadkich i ginących. Celem polityki łowieckiej w warunkach polskich, stanowiącej element ochrony środowiska przyrodniczego, jest zróżnicowany rozwój populacji zwierząt łownych i ochrona jej różnorodności w powiązaniu z gospodarką leśną, rolną i rybacką" (s. 33-34).

Generalnie opracowanie szeroko odwołuje się do literatury prawniczej i orzecznictwa oraz niewątpliwie pokazuje ścisłe związki z praktyką łowiecką jednego z autorów. Można jednak w niektórych miejscach zarzucić mu pewną nieprzejrzystość, wynikającą z nieproporcjonalnego pomieszania wątków ważniejszych z pobocznymi, często nadmiernie eksponowanymi.

W 2015 r. na rynku wydawniczym pojawił się komentarz autorstwa Adama Pązika i Marcina Słomskiego ${ }^{27}$. Pierwszy z autorów to doktor nauk prawnych, adwokat specjalizujący się w prawie cywilnym, zaś drugi - także doktor nauk prawnych, to również czynny myśliwy.

Swojemu opracowaniu autorzy zamierzają nadać przede wszystkim charakter praktyczny i kierują je przede wszystkim do osób zajmujących się prawem łowieckim (myśliwych, prawników praktyków, wykładowców, Zarządów Okręgowych PZŁ, zarządów kół łowieckich). Jego przedmiotem jest przede wszystkim analiza ustawy przez pryzmat orzecznictwa sądowego wydanego w związku z nią. Odwołania do literatury prawniczej oraz komentarzy mają jedynie charakter uzupełniający (stanowią relatywnie krótkie i syntetyczne uzupełnienie już istniejącej na rynku prawniczym literatury - s. 17). 
Praca zbudowana jest w oparciu o krótki wstęp, komentarz do kolejnych przepisów ustawy Prawo łowieckie, wykaz literatury i orzecznictwa. Wprawdzie autorzy nie nawiązują literalnie do prawa ochrony środowiska (prawa ochrony przyrody), to jednak prawo łowieckie jest dla nich $\mathrm{w}$ istocie prawem ochrony zwierząt - reguluje ochronę zwierząt, stanowi jeden z elementów ochrony środowiska przyrodniczego (s. 22). Prowadzenie gospodarki łowieckiej powinno następować na zasadzie osiągnięcia „złotego środka” między wymogami ekologii a zasadami racjonalnej gospodarki rolnej, leśnej oraz rybackiej. Z kolei za racjonalną należy uznać taką gospodarkę łowiecką, która z jednej strony pozwala na zachowanie gatunków zwierząt łownych, zaś z drugiej nie prowadzi do niekontrolowanego rozwoju ich populacji, co mogłoby narazić na poważne szkody np. rolnictwo lub inne formy działalności ludzkiej (s. 23).

\section{PODSUMOWANIE I KONKLUZJE}

Lektura przywołanych prac pozwala na pewne uogólnienia. Wskażemy je według zaproponowanego na wstępie schematu.

Po pierwsze, jeżeli chodzi o koncepcje poszczególnych komentarzy, to jest ona zbliżona $\mathrm{w}$ tym sensie, że następuje omówienie poszczególnych przepisów obowiązującej w danym kraju ustawy (nawet wtedy, gdy nie są omówione wszystkie przepisy, jak w komentarzu słowackim). W zróżnicowanym stopniu następuje odwoływanie się do literatury i orzecznictwa sądowego, co można wytłumaczyć zarówno dorobkiem tegoż (ilościowo jest on różnorodny w poszczególnych krajach), jak i dozwoloną swobodą badawczą opierającą się na prawie autora do wskazania czytelnikowi tego, co uważa za najistotniejsze. Po drugie, nie ma żadnych wątpliwości, że wszędzie prawo łowieckie traktowane jest jako dział prawa ochrony środowiska, zaś łowiectwo to działalność, w której na pierwszy plan wysuwają się motywy ochronne. Nawet jeśli niektórzy autorzy wprost nie wskazują na prawo ochrony środowiska 
(przyrody), to takie ujęcie łowiectwa wprost wynika z ustaw, i przewija się w uwagach komentatorskich. Po trzecie, co jest czynnikiem decydującym o atrakcyjności komentarza dla czytelnika - w tej kwestii musimy naszkicować pewien wzorzec opracowania o charakterze komentatorskim i umiejscowić go w ramach literatury prawniczej.

Banalne jest stwierdzenie, że od komentarza oczekujemy objaśnienia przepisów prawnych, rozwiania wątpliwości interpretacyjnych, a przynajmniej wskazania takiej wykładni, która jest logiczna, racjonalna i dobrze umocowana w innych częściach systemu prawnego oraz wypowiedziach orzecznictwa i doktryny. Krótko mówiąc, po dobrym komentarzu spodziewamy się oryginalnych poglądów autora co do rozumienia i sensu danego przepisu, przy czym przez oryginalność rozumiemy odniesienie się i propozycje rozwiązania pojawiających się w praktyce problemów interpretacyjnych.

W tym kontekście nie oczekujemy od komentarza w tym komentarza „łowieckiego” - upartego przywoływania literatury czy orzecznictwa, które w ogóle, bądź w bardzo luźnym związku pozostaje ze wskazanym problemem interpretacyjnym. Czytelnik komentarza, często będący praktykiem, na przykład myśliwym czy działaczem administracji łowieckiej, nie oczekuje nawarstwiania sporów doktrynalnych, ale spodziewa się racjonalnej i raczej zwięzłej propozycji rozwiązania problemu praktycznego, wynikającego z brzmienia przepisu. Często bywa tak, że czytelnik zainteresowany komentarzem nie poszukuje ,światła” pozwalającego dojrzeć wszelkie kontrowersje i problemy prawnicze, ale „podparcia” umożliwiającego wzmocnienie oczekiwanego przez niego rozstrzygnięcia kwestii prawnej. Nadmiar różnorakich informacji może dla takiego odbiorcy problem zamazać, a wręcz ukryć, a nie uwypuklić i rozwiązać. W tym znaczeniu nie należy zbliżać komentarza do monografii naukowej czy dzieła o charakterze systemowym, z podstawowego powodu - zasadniczo innego odbiorcy i odmiennych oczekiwań.

Autor komentarza nie powinien jednak uciekać od szerszego umiejscowienia komentowanych przepisów biorąc pod 3/2016 uwagę, że omawiany przepis prawny stanowi część aktu 
prawnego, który to akt składa się na pewną dziedzinę (dział) prawa, która z kolei jest częścią systemu prawa polskiego, ale też prawa unijnego i międzynarodowego. Na tej płaszczyźnie można dostrzec pewien mankament opracowań przygotowanych przez tzw. praktyków, którzy doskonale znając problemy związane $\mathrm{z}$ ich specjalnością, pomijają szerszy kontekst prawny.

Na koniec chcemy podkreślić, że celem naszego opracowania nie była ocena poszczególnych komentarzy, biorąc pod uwagę proponowane rozwiązania problemów interpretacyjnych czy staranność warsztatową i badawczą autorów. Przynajmniej $\mathrm{w}$ tej pierwszej kwestii wymagałoby to napisania kolejnego komentarza. Chcieliśmy przedstawić charakter tego typu opracowań z szerszej, ponadkrajowej i komparatystycznej perspektywy, wypowiedzieć się w sprawie charakteru komentarza jako opracowania prawniczego i zasygnalizować, że komentarz do ustawy łowieckiej z natury rzeczy musi odróżniać się od dzieła typu Polskie prawo łowieckie, któremu należałoby nadać bardziej teoretyczny i systemowy charakter.

\section{BIBLIOGRAFIA}

Cepek B. a kolektiv, Environmentálne pravo. Všeobecná a osobitná čast’, Plzeň 2015.

Čechura V. a kolektiv, Myslivost a právo, Praha 2000.

Čechura V., Novák R., Vaněk J., Komentář k zákonu o myslivosti, Praha 2002.

Jančařová I. a kolektiv, Právo životního prostředí. Zvlaštní čast, Brno 2015.

Kolektiv autorů, Pravo životního prostředí. 2. dil, Brno 2006.

Košičiarová S. a kolektiv, Pravo životného prostredia, Bratislava 2009.

L’uptak M., Sarvaš M., Zákon o pol'ovnictve. Komentár k vybraným ustanoveniam, Bratislava 2015.

Matečny J. a kolektiv, Právne predpisy o pol'ovnictve, Bratislava 1977.

Muller T., Zwolak Z. Prawo towieckie z komentarzem oraz przepisami wykonawczymi i zwiąkowymi, Warszawa 1998.

Petr B. a kolektiv, Zákon o myslivosti. Komentáŕ, Praha 2015. 
Pązik A., Słomski M., Prawo łowieckie. Komentarz, Warszawa 2015.

Radecki W. Prawo towieckie. Komentarz, Warszawa 2014.

Skocka M. J., Szczepański J., Prawo towieckie. Komentarz, Warszawa 1998.

Stec R., Rakoczy B., Woźniak A., Prawo łowieckie. Komentarz, Warszawa 2014.

Kontakt e-mail:

adh@interia.pl 